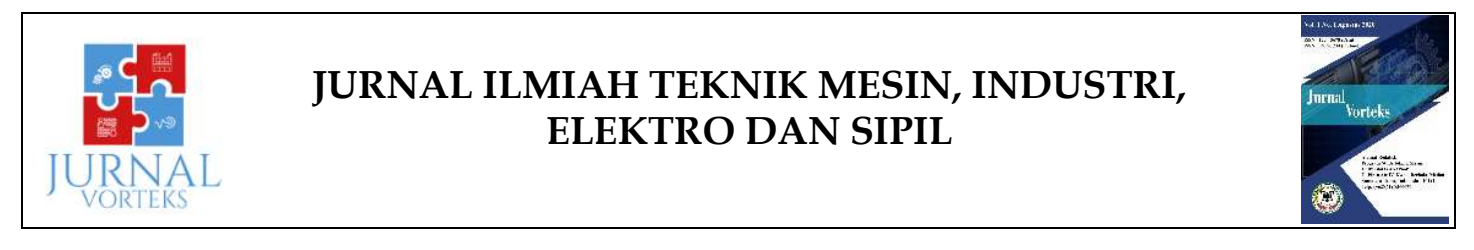

\title{
PENGUJIAN KARAKTERISTIK SEPATU KUDA BAHAN KOMPOSIT POLYMERIC FOAM BERPENGUAT FIBERGLASS MENGGUNAKAN UJI GESEK DAN PENGAMATAN MIKROSKOP
}

\author{
Mawardi $^{1}$, Bustami Syam ${ }^{2}$ \\ ${ }^{1}$ Program Studi Teknik Mesin Fakultas Teknik Universitas Al-Azhar Medan, Jl. Pintu Air IV No.214, \\ Kwala Bekala, Kec. Medan Johor, Kota Medan, Sumatera Utara 20143 \\ ${ }^{2}$ Penanggung Jawab Laboratorium Pusat Riset Impak dan Keretakan (IFRC) Departemen Teknik \\ Mesin Universitas Sumatera Utara, Jl. Dr. T. Mansur No.9, Padang Bulan, Kec. Medan Baru, Kota \\ Medan, Sumatera Utara 20222 \\ E-mail: mawardi.ipc@gmail.com
}

\begin{abstract}
ABSTRAK
Hasil pengujian gesek (keausan) Spesimen A nilai rata-rata untuk lebar jejak keausan (ā) $1616 \mu \mathrm{m}$ kedalaman jejak keausan $(\bar{b}) 546.17 \mu \mathrm{m}$, volume keausan eksperimental $\left(V_{p}\right) 9.575 \mathrm{~mm}^{3}$ dan laju keausan $\left(\psi_{P}\right) 0.10 \mathrm{~mm}^{3} / \mathrm{s}$. Spesimen B dengan nilai rata-rata untuk lebar jejak keausan $(\overline{\mathrm{a}}) 2526.26$ $\mu \mathrm{m}$, kedalaman jejak keausan $(\bar{b}) 2033.18 \mu \mathrm{m}$, volume keausan eksperimental $\left(V_{p}\right) 2.573 \mathrm{~mm}^{3}$ dan laju keausan $\left(\psi_{P}\right) 0.31 \mathrm{~mm}^{3} / \mathrm{s}$. Spesimen C nilai rata-rata untuk lebar jejak keausan $(\bar{a}) 1079.87 \mu \mathrm{m}$, kedalaman jejak keausan $(\bar{b}) 266.10 \mu \mathrm{m}$, volume keausan eksperimental $\left(V_{p}\right) 1.253 \mathrm{~mm}^{3}$ dan laju keausan $\left(\psi_{P}\right) 0.041 \mathrm{~mm}^{3} / \mathrm{s}$. Spesimen D nilai rata-rata untuk lebar jejak keausan $(\overline{\mathrm{a}}) 1728.20 \mu \mathrm{m}$, kedalaman jejak keausan $(\bar{b}) 712.27 \mu \mathrm{m}$, volume keausan eksperimental $\left(V_{p}\right) 3.354 \mathrm{~mm}^{3}$ dan laju keausan $\left(\psi_{P}\right) 0.11 \mathrm{~mm}^{3} / \mathrm{s}$. Spesimen E nilai rata-rata untuk lebar jejak keausan $(\bar{a}) 1788.32 \mu \mathrm{m}$, kedalaman jejak keausan $(\bar{b}) \quad 1101.40 \mu \mathrm{m}$, volume keausan eksperimental $\left(V_{p}\right) 5.187 \mathrm{~mm}^{3}$ dan laju keausan $\left(\psi_{P}\right) 0.17 \mathrm{~mm}^{3} / \mathrm{s}$.
\end{abstract}

Kata Kunci : Kehausan, Spesimen, Eksperimental, Hasil pengujian

\section{ABSTRACT}

The results of the friction (wear) test Specimen A mean value for the wear trail width (a) $1616 \mu \mathrm{m}$ wear trace depth $(\bar{b}) 546.17 \mu \mathrm{m}$, experimental wear volume $(\mathrm{Vp}) 9,575 \mathrm{~mm}^{3}$ and wear rate $(\psi P) 0.10 \mathrm{~mm} 3$ / s. Specimen $B$ with average values for the wear trail width $(\bar{a}) 2526.26 \mu \mathrm{m}$, the wear trace depth $(\bar{b})$ $2033.18 \mu \mathrm{m}$, experimental wear volume (Vp) $2,573 \mathrm{~mm}^{3}$ and wear rate $(\psi P) 0.31 \mathrm{~mm} 3 / \mathrm{s}$. Specimen C mean values for wear trace width $(\bar{a}) 1079.87 \mu \mathrm{m}$, wear trace depth $(\bar{b}) 266.10 \mu \mathrm{m}$, experimental wear volume (Vp) $1.253 \mathrm{~mm}^{3}$ and wear rate $(\psi P) 0.041 \mathrm{~mm} 3 / \mathrm{s}$. Specimen D mean values for wear trace width (a) $1728.20 \mu \mathrm{m}$, wear trace depth $(\bar{b}) 712.27 \mu \mathrm{m}$, experimental wear volume $(\mathrm{Vp}) 3.354 \mathrm{~mm}^{3}$ and wear rate $(\psi P) 0.11 \mathrm{~mm} 3 / \mathrm{s}$. Specimen E mean values for wear trace width $(\bar{a}) 1788.32 \mu \mathrm{m}$, wear trace depth $(\bar{b}) 1101.40 \mu \mathrm{m}$, experimental wear volume $(\mathrm{Vp}) 5.187 \mathrm{~mm}^{3}$ and wear rate $(\psi P) 0.17 \mathrm{~mm} 3 / \mathrm{s}$.

Keywords : Wear, Specimen, Experimental, The Result

Hal 1 dari 43

JURNAL VORTEKS, Vol. 01 No. 01, Oktober 2020 p-ISSN :

Website : http://jurnal.alazhar-university.ac.id/index.php/vorteks

e-ISSN : 


\section{JURNAL ILMIAH TEKNIK MESIN, INDUSTRI, ELEKTRO DAN SIPIL}

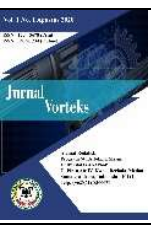

\section{PENDAHULUAN}

Populasi kuda (Horse Population by Province) saat ini tahun 2017 di Indonesia menurut Direktorat Jenderal Peternakan dan Kesehatan Hewan (Directorate Generale of Livestock and Animal Health Research) sebanyak 442.602 ekor, khusus Sumatera Utara sebanyak 1.686 ekor (pertumbuhannya 1,75\%) [1]. Kawasan Berastagi dimana kuda berjalan tiap hari pada daerah yang beraspal dan cor beton memakai sepatu dari bahan steel. Kawasan wisata ini pada hari libur aktivitas kuda bergerak terus seharian sehingga pemakaian sepatu kuda bahan steel ini sangatlah boros, usia sepatu kuda relatif lebih cepat hingga 1-2 minggu sekali sudah harus diganti dibanding dengan hari biasa dimana penggantian sepatu kuda usianya 4 minggu sekali. Sepatu kuda dirancang khusus sebagai lapisan pelindung antara medan yang dilaluinya dengan kuku kuda, dimana sepatu kuda menyerap kekuatan benturan yang menyebabkan kerusakan pada dinding kuku. Permasalahnnya adalah tingkat keausan dari bahan baja ini cukup tinggi sehingga pemakaiannya relatif cepat. Aus terjadi karena adanya kontak gesekan antara dua benda yang menyebabkan perpindahan material. Keausan umumnya didefinisikan sebagai kehilangan material secara progresif akibat adanya gesekan (friksi) antar permukaan padat hasil dari pergerakan relatif antara permukaan tersebut dan permukaan lainnya [2]. Rekayasa sepatu kuda dari bahan alternatif polymeric foam menjadi perhatian utama untuk mengurangi permasalahan yang ada. Penelitian dengan menganalisa karakteristik dan struktur sepatu kuda dari beberapa komposisi bahan penyusun. Fiberglass diolah dengan bahan resin thermoset tak jenuh type 157 BQTN-Ex dan campuran bahan lain katalis dari jenis MEKPO untuk mempercepat proses polimerisasi. Polyurethane adalah campuran polyol dan isocianate sebagai blowing agent diolah menjadi polymeric foam. Menguji keausan pada lima komposisi spesimen uji standar ASTM G99-04 [3]

\section{TINJAUAN PUSTAKA}

Pada tahun 1861 M, J.B. Kendall mematenkan sepatu kuda bahan komposit pertama. Beberapa tahun kemudian, Oscar E. Brown menemukan tapal kuda ganda pada tahun 1892 M [4]. Pada desain struktur dilakukan pemilihan matriks dan penguat, hal ini dilakukan untuk memastikan kemampuan material sesuai dengan produk yang akan dihasilkan. Material yang akan diuji menggunakan bahan dasar komposit. Komposit merupakan gabungan, campuran dua atau lebih bahan bahan yang terpisah. Komposit dikenal sebagai bahan teknologi karena diperoleh dari hasil teknologi pengolahan bahan. Kemajuan teknologi pengolahan bahan dewasa ini telah menghasilkan bahan teknik dikenal sebagai komposit [5].

Output yang dihasilkan dari penelitian ini adalah sepatu kuda berbahan komposit. Kuda yang berdiri memiliki keseimbangan gaya linier keatas akibat berat badan kuda (F) dan keseimbangan gaya kebawa kebawah (R) yang bekerja melawan gaya ke bawah. Dengan konvensi kekuatan gaya keatas (F) adalah posistif dan kekuatan konvensi yang sama arah berlawanan negatif (-W). Persamaan ini merupakan pengukuran empiris dari kekasaran permukaan. Empiris berarti didapat dari pengalaman dapat dihitung dengan persamaan:

$$
\mathrm{F}-\mathrm{W}=0
$$

Dimana: akibat berat kuda

$+\mathrm{F} \quad$ : Gaya yang mengarah ke atas.

- W : Gaya langsung ke bawah Gaya gesek terbagi tiga yaitu statis, geser, dan berguling gaya gesek persamaannya adalah:

$$
\mathrm{H}=\mu \mathrm{F}
$$

Dimana:

$$
\begin{array}{ll}
\mathrm{H} & : \text { Gesekan } \\
\mathrm{F} & : \text { Gaya reaksi }
\end{array}
$$

Fungsi gesekan dan gesekan $(\mathrm{H})$ adalah fungsi dari berat kuda (F) pada kaki dan kekasaran permukaan $(\mu)$. Jelas mengenakan gesekan akan meningkat karena berat kuda dan pengendara meningkat atau kekasaran, kekakuan

Hal 2 dari 43 


\section{JURNAL ILMIAH TEKNIK MESIN, INDUSTRI, ELEKTRO DAN SIPIL}

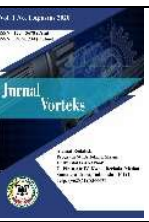

permukaan meningkat [6]. Berdasarkan hukum keausan Archard tentang hukum keausan bahwa persamaan volume keausan dapat diperoleh dari:

$$
\begin{aligned}
& V_{T}=K \frac{W_{X} L}{H} 10^{9} \\
& \psi_{T}=\frac{v_{T}}{t}
\end{aligned}
$$

Menghitung panjang lintasan $(L)$ pada pengujian keausan ini, dapat kita gunakan persamaan sebagai berikut:

$$
\begin{aligned}
& L=\frac{2 . \pi \cdot r \cdot n \cdot t}{60} \\
& r=\frac{d+(\bar{a}) \times 10^{-3}}{2}
\end{aligned}
$$

Dimana:

$\begin{array}{rlll}V_{T} & : & \text { Volume keausan teori } & \left(\mathrm{mm}^{3}\right) \\ K & : & \text { Koefisien keausan } & \left(6.0 \times 10^{-4}\right) \\ W & : & \text { Beban } & (\mathrm{N}) \\ H & : & \text { Kekerasan material } & \left(\mathrm{Pa}, \mathrm{N} / \mathrm{m}^{2}\right) \\ L & : & \text { Panjang Lintasan } & (\mathrm{m}) \\ \psi_{T} & : & \text { Laju keausan teori } & \mathrm{Mm}^{3} / \text { detik } \\ t & : & \text { Waktu keausan } & \text { detik }\end{array}$

\section{METODOLOGI}

Pada pengujian keausan mesin yang digunakan tipe pin on disc standar spesimen ASTM G9904 dilakukan dengan variasi komposisi Keausan yang terjadi pada pengujian ini adalah keausan abrasif. Karakteristik mekanik yang diinginkan dari penelitian ini adalah lebar jejak keausan $(\bar{a})$, kedalaman jejak keausan $(\bar{b})$, volume keausan eksperimental $\left(V_{p}\right)$ dan laju keausan $\left(\psi_{P}\right)$ pada variabel komposisi A, B, C, D dan E. Setelah dilakukan pengujian gesek, hasilnya akan dilakukan pengamatan pada alat uji mikroskop untuk mengetahui lebar jejak keausan spesimen menggunakan alat uji Reflected Microscope HIROX Type MXB 2500 $R E Z$ pembesaran 2000 kali pembesaran.
Tabel 1. Spesifikasi spesiemen uji kehausan

\begin{tabular}{ccccc}
\hline No & Spesimen & $\begin{array}{c}\text { Beban } \\
\text { pin on } \\
\text { disc } \\
\text { (kg) }\end{array}$ & $\begin{array}{c}\text { Putaran } \\
\text { Mesin } \\
\text { (Rpm) }\end{array}$ & $\begin{array}{c}\text { Waktu } \\
\text { (detik) }\end{array}$ \\
\hline 1 & $\mathrm{~A}$ & 1 & 120 & 30 \\
2 & $\mathrm{~B}$ & 1 & 120 & 30 \\
3 & $\mathrm{C}$ & 1 & 120 & 30 \\
4 & $\mathrm{D}$ & 1 & 120 & 30 \\
5 & $\mathrm{E}$ & 1 & 120 & 30 \\
\hline & & & & \\
& & & &
\end{tabular}

Gambar 1. Mesin uji Pin On Disc dan Mikroskop Hirox 2500

Mendapatkan tingkat keausan bahan penyusun komposit polymeric foam reinforce fiberglass ini maka dilakukan produksi spesimen uji dengan lima komposisi masing-masing lima spesimen uji lalu diuji gesek dengan standar American Standard Testing of Material (ASTM) G99-04. Komposisi tersebut seperti terlihat pada table 2 berikut.

Tabel 2. Persentase komposisi uji keausan

\begin{tabular}{lccccc}
\hline $\begin{array}{l}\text { Material } \\
\text { Penyusun }\end{array}$ & $\begin{array}{c}\text { Komp } \\
\text { osisi A } \\
\% \\
(\mathrm{ml})\end{array}$ & $\begin{array}{c}\text { Komposi } \\
\text { si B } \\
\%(\mathrm{ml})\end{array}$ & $\begin{array}{c}\text { Komposi } \\
\text { si C } \\
\%(\mathrm{ml})\end{array}$ & $\begin{array}{c}\text { Komposi } \\
\text { si D } \\
\%(\mathrm{ml})\end{array}$ & $\begin{array}{c}\text { Komposi } \\
\text { si E } \\
\%(\mathrm{ml})\end{array}$ \\
\hline Resin & $65(25)$ & $60(23.1)$ & $55(21.2)$ & 50 & $45(17.3)$ \\
& & & & $(19.25)$ & \\
Blowing & 20 & $25(7.7)$ & $30(11.5)$ & $35(13.5)$ & $40(15.4)$ \\
$\begin{array}{l}\text { Kgent } \\
\text { Katalis }\end{array}$ & $(7.7)$ & & & & \\
Fiberglass & $5(1.9)$ & $5(3.85)$ & $5(1.9)$ & $5(1.9)$ & $5(1.9)$ \\
& $(3.85)$ & $10(3.85)$ & $10(3.85)$ & $10(3.85)$ & $10(3.85)$ \\
\hline
\end{tabular}

\section{HASIL DAN PEMBASAHAN}

Penelitian ini menggunakan metode pengujian gesek dilakukan terhadap spesimen sepatu kuda. Jenis mesin yang dipakai adalah pin on disc. Variabel yang diamati pertama panjang lintasan (L). Kedua luas dalam dan luar lintasan (A1 dan ) A2). Ketiga volume keausan dan laju keausan eksperimental (Vp). Spesimen uji dipasang mesin pin on disc. Spesimen sebelum dilakukan pengujian memiliki ukuran yang sama dengan tebal $\left(t_{1}\right) 10 \mathrm{~mm}$, diameter

Hal 3 dari 43 


\section{JURNAL ILMIAH TEKNIK MESIN, INDUSTRI, ELEKTRO DAN SIPIL}

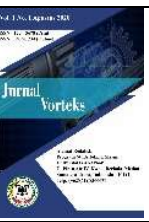

spesimen $(d) 70 \mathrm{~mm}$, Volume awal $\left(V_{a}\right) 38.46$ $\mathrm{mm}^{3}$. Perbedaan hanya pada variasi komposisi. Variasi komposisi A, B, C, D dan E pada putaran mesin tetap $120 \mathrm{rpm}$ dengan beban tetap satu $1 \mathrm{~kg}$ selama waktu masing-masing 30 detik dilakukan pada uji keausan pin on disc. Nilai putaran mesin diambil berdasarkan kecepatan berlari maksimum kuda (equus ferus caballus) adalah $88 \mathrm{~km} / \mathrm{jam}=120 \mathrm{rpm}$ [7].

Spesimen uji A, B, C, D dan E yang diproduksi setelah mengalami uji gesek pada mesin pin on disc diperlihatkan pada gambar 2

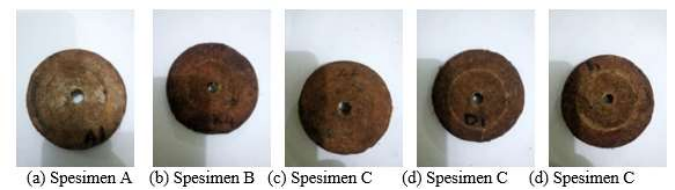

Gambar 2. Spesimen uji gesek lima spesimen A, b, C, D dan E

1. Pengujian Keausan Spesimen A

Hasil pengujian gesek dan pengamatan mikroskop spesimen A ditunjukkan pada gambar 3

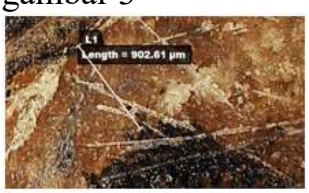

(a) Lebar jejak Spesimen A1

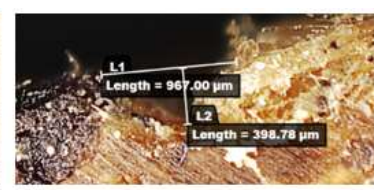

(b) Kedalaman jejak spesimen A2
Gambar 3. Lebar jejak dan kedalaman jejak keausan Spesimen A

Secara global hasil pengujian gesek spesimen A dapat kita lihat pada tabel 3 berikut.

Tabel 3. Lebar dan kedalaman jejak keausan

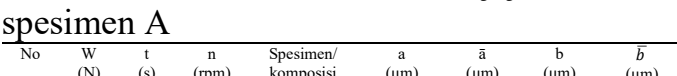

\begin{tabular}{ccccccccc}
\hline No & $\begin{array}{c}\mathrm{W} \\
(\mathrm{N})\end{array}$ & $\begin{array}{c}\mathrm{t} \\
(\mathrm{s})\end{array}$ & $\begin{array}{c}\mathrm{n} \\
(\mathrm{rpm})\end{array}$ & $\begin{array}{c}\text { Spesimen/ } \\
\text { komposisi }\end{array}$ & $\begin{array}{c}\mathrm{a} \\
(\mu \mathrm{m})\end{array}$ & $\begin{array}{c}\bar{a} \\
(\mu \mathrm{m})\end{array}$ & $\begin{array}{c}\mathrm{b} \\
(\mu \mathrm{m})\end{array}$ & $\begin{array}{c}\bar{b} \\
(\mu \mathrm{m})\end{array}$ \\
\hline 1 & 10 & 30 & 120 & $\mathrm{~A} 1$ & 902.61 & 1616 & 716.09 & 546.17 \\
2 & 10 & 30 & 120 & $\mathrm{~A} 2$ & 1981.03 & & 398.78 & \\
3 & 10 & 30 & 120 & $\mathrm{~A} 3$ & 1964.32 & & 523.65 & \\
\hline
\end{tabular}

2. Pengujian Keausan Spesimen B

Hasil pengujian gesek dan pengamatan mikroskop spesimen B ditunjukkan pada gambar 4
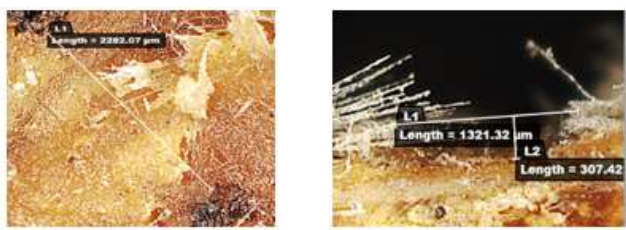

(a) Lebar Jejak Spesimen B3 $\quad$ (b) Kedalaman Jejak spesimen B3

Gambar 4. Lebar jejak dan kedalaman jejak keausan Spesimen B

Hasil pengamatan uji gesek dan mikrostruktur menggunakan mikroskop kita lihat pada tabel 4

Tabel 4. Lebar dan kedalaman jejak keausan spesimen B

\begin{tabular}{|c|c|c|c|c|c|c|c|c|}
\hline No & $\begin{array}{c}\mathrm{W} \\
(\mathrm{N})\end{array}$ & $\begin{array}{c}\mathrm{t} \\
\text { (s) }\end{array}$ & $\begin{array}{c}\mathrm{n} \\
(\mathrm{rpm})\end{array}$ & Spesimen & $\begin{array}{c}\mathrm{a} \\
(\mu \mathrm{m})\end{array}$ & $\begin{array}{c}\overline{\bar{a}} \\
(\mu \mathrm{m})\end{array}$ & $\begin{array}{c}\mathrm{b} \\
(\mu \mathrm{m})\end{array}$ & $\begin{array}{c}\overline{\mathrm{b}} \\
(\mu \mathrm{m})\end{array}$ \\
\hline 1 & 10 & 30 & 120 & B1 & 2436.83 & & 818.45 & \\
\hline $\begin{array}{l}2 \\
3\end{array}$ & $\begin{array}{l}10 \\
10\end{array}$ & $\begin{array}{l}30 \\
30\end{array}$ & $\begin{array}{l}120 \\
120\end{array}$ & $\begin{array}{l}\text { B2 } \\
\text { B3 }\end{array}$ & $\begin{array}{l}2859.88 \\
2282.07\end{array}$ & 2526.26 & $\begin{array}{l}674.65 \\
307.42\end{array}$ & 600.17 \\
\hline
\end{tabular}

3. Pengujian Keausan Spesimen C Hasil pengujian gesek dan pengamatan mikroskop spesimen C ditunjukkan pada gambar

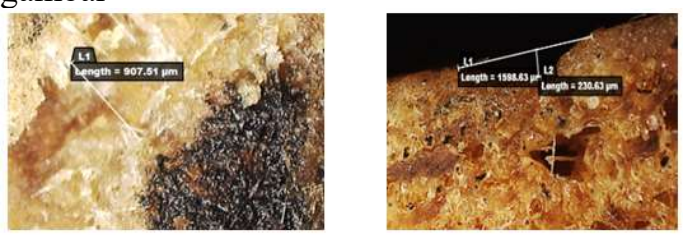

(a) Lebar jejak keusan spesimen C3 (b) Kedalaman jejak keausan spesimen C3

Gambar 5. Lebar jejak dan kedalaman jejak keausan Spesimen C

Hasil pengamatan uji gesek dan diamati menggunakan mikroskop diperlihatkan pada tabel dibawah ini.

Tabel 5. Lebar dan kedalaman jejak keausan spesimen C

\begin{tabular}{|c|c|c|c|c|c|c|c|c|}
\hline No & $\begin{array}{c}\mathrm{W} \\
(\mathrm{N})\end{array}$ & $\begin{array}{c}\mathrm{t} \\
\text { (s) }\end{array}$ & $\begin{array}{c}\mathrm{n} \\
(\mathrm{rpm})\end{array}$ & Spesimen & $\begin{array}{c}\mathrm{a} \\
(\mu \mathrm{m})\end{array}$ & $\begin{array}{c}\bar{a} \\
(\mu \mathrm{m})\end{array}$ & $\begin{array}{c}\mathrm{b} \\
(\mu \mathrm{m})\end{array}$ & $\overline{\bar{b}}(\mu \mathrm{m})$ \\
\hline 1 & 10 & 30 & 120 & $\mathrm{Cl}$ & 1340.62 & & 288.07 & \\
\hline 2 & 10 & 30 & 120 & C2 & 991.48 & 1079.87 & 284.60 & 266.10 \\
\hline 3 & 10 & 30 & 120 & C3 & 907.51 & & 230.63 & \\
\hline
\end{tabular}

\section{Pengujian Keausan Spesimen D}

Hasil pengujian gesek dan pengamatan mikroskop spesimen D ditunjukkan pada gambar 


\section{JURNAL ILMIAH TEKNIK MESIN, INDUSTRI, ELEKTRO DAN SIPIL}

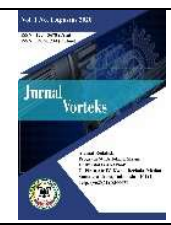

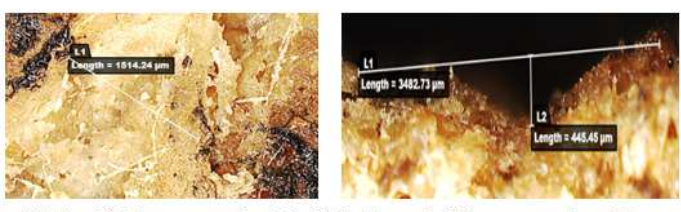

(a) Lebar jejak keausan spesimen D2 (b) Kedalaman jejak keausan spesimen D3

Gambar 6. Lebar jejak dan kedalaman jejak keausan Spesimen D

Hasil pengamatan uji gesek dan diamati menggunakan mikroskop kita lihat pada tabel 5

Tabel 6. Lebar dan kedalaman jejak keausan spesimen D

\begin{tabular}{ccccccccc}
\hline No & $\begin{array}{c}\mathrm{W} \\
(\mathrm{N})\end{array}$ & $\begin{array}{c}\mathrm{t} \\
(\mathrm{s})\end{array}$ & $\begin{array}{c}\mathrm{n} \\
(\mathrm{rpm})\end{array}$ & $\begin{array}{c}\text { Spesimen/ } \\
\text { Komposisi }\end{array}$ & $\begin{array}{c}\mathrm{a} \\
(\mu \mathrm{m})\end{array}$ & $\begin{array}{c}\overline{\mathrm{a}} \\
(\mu \mathrm{m})\end{array}$ & $\begin{array}{l}\mathrm{b} \\
(\mu \mathrm{m})\end{array}$ & $\begin{array}{c}\bar{b} \\
(\mu \mathrm{m})\end{array}$ \\
\hline 1 & 10 & 30 & 120 & $\mathrm{D} 1$ & 2011.43 & & 734.51 & \\
2 & 10 & 30 & 120 & $\mathrm{D} 2$ & 1514.24 & 1728.20 & 956.84 & 712.27 \\
3 & 10 & 30 & 120 & $\mathrm{D} 3$ & 1658.92 & & 445.45 & \\
\hline
\end{tabular}

5. Pengujian Keausan Spesimen E

Hasil pengujian gesek dan pengamatan mikroskop spesimen E ditunjukkan pada gambar berikut ini

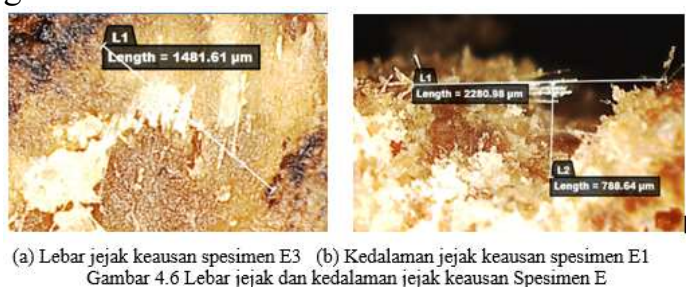

Gambar 7. Lebar jejak dan kedalaman jejak keausan Spesimen E

Hasil pengamatan uji gesek dan diamati menggunakan mikroskop kita lihat pada tabel 7

Tabel 7. Lebar dan kedalaman jejak keausan spesimen E

\begin{tabular}{|c|c|c|c|c|c|c|c|c|}
\hline No & $\begin{array}{c}\mathrm{W} \\
(\mathrm{N}) \\
\end{array}$ & t & $\begin{array}{c}\mathrm{n}(\mathrm{n}) \\
(\mathrm{r} m)\end{array}$ & $\begin{array}{l}\text { Spesimen/ } \\
\text { komposis }\end{array}$ & $\mathrm{a}(\mu \mathrm{m})$ & $\overline{\bar{a}(\mu \mathrm{m})}$ & $\mathrm{b}(\mu \mathrm{m})$ & $\bar{b}(\mu \mathrm{m})$ \\
\hline $\begin{array}{l}1 \\
2 \\
3 \\
\end{array}$ & $\begin{array}{l}10 \\
10 \\
10\end{array}$ & $\begin{array}{l}30 \\
30 \\
30\end{array}$ & $\begin{array}{l}120 \\
120 \\
120\end{array}$ & $\begin{array}{l}\text { E1 } \\
\text { E2 } \\
\text { E3 }\end{array}$ & $\begin{array}{l}2006.03 \\
19787.32 \\
1481.61\end{array}$ & 1788.32 & $\begin{array}{l}788.64 \\
1221.59 \\
129396\end{array}$ & 1101.40 \\
\hline
\end{tabular}

Dari hasil pengujian keausan untuk lima spesimen A, B, C, D dan E dimana lebar dan kedalaman jejak keausan telah dilakukan pengamatan, sehingga nilai jejak keausan rata rata yang terjadi pada spesimen bahan polymeric foam yang diperkuat fiberglass dirangkum dalam sebuah tabel seperti yang diperlihatkan pada tabel dibawah ini.
Tabel 8. Lebar dan kedalaman jejak rata-rata pengujian keausan

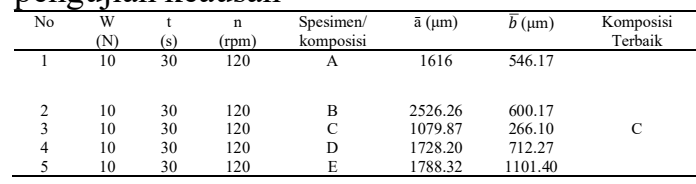

Lebar jejak keausan dimanfaatkan untuk menghitung panjang lintasan keausan pada hukum Archard, maka didapatlah volume keausan bahan. Kedalaman jejak dimanfaatkan untuk menghitung volume keausan eksperimental dapat dilihat pada tabel 9

6. Signifikasi Laju Keausan terhadap usia sepatu kuda

Laju keausan terbaik adalah pada komposisi C dimana:

$$
\begin{aligned}
\psi_{\mathrm{P}} & =\frac{\mathrm{V}_{\mathrm{P}}}{\mathrm{t}} \\
& =\frac{1.25 \mathrm{~mm}^{3}}{30 \mathrm{~s}} \\
& =0.04 \mathrm{~mm}^{3} / \mathrm{s}
\end{aligned}
$$

Dalam satu detik terjadi laju keausan pada spesimen sepatu kuda sebesar $0.04 \mathrm{~mm}^{3}$.

Diketahui:

$>1 \mathrm{~mm}^{3}=0.001 \mathrm{~mm}, 1$ detik $=0.04$ $\times 0.001=0.000004 \mathrm{~mm}$

$>$ Dalam 1 detik terjadi keausan sebesar : $0.000004 \mathrm{~mm}$

$>1$ hari $=86.400$ detik $\times 0.000004 \mathrm{~mm}$ $=0.2 \mathrm{~mm}-0.3 \mathrm{~mm}$

Maka asumsi usia pakai sepatu kuda dengan tebal $10 \mathrm{~mm}$ dalam keadaan kontinyu terus menerus berjalan pada hari libur dan harihari besar besar dimana kuda berjalan jam tayangnya lebih banyak akan terjadi keausan selama $6-8$ minggu, namun jika hari biasa usia sepatu kuda akan lebih lama tergantung pemakaian. Laju keausa dengan variasi komposisi dalam waktu yang tetap 30 menit, putaran mesin yang tetap $120 \mathrm{rpm}$ dan diameter spesimen yang sama $35 \mathrm{~mm}$ dapat kita lihat pad tabel 9 berikut

Hal 5 dari 43 


\section{JURNAL ILMIAH TEKNIK MESIN, INDUSTRI, ELEKTRO DAN SIPIL}

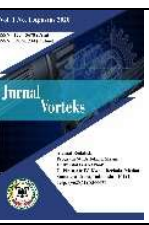

Tabel 9. Laju keausan dengan variasi komposisi

\begin{tabular}{cccccccccc}
\hline No & $\begin{array}{c}\mathrm{W} \\
(\mathrm{N})\end{array}$ & $\begin{array}{c}\mathrm{t} \\
(\mathrm{s})\end{array}$ & $\begin{array}{c}\mathrm{n} \\
(\mathrm{prm})\end{array}$ & $\begin{array}{c}d_{1} \\
(\mathrm{~mm})\end{array}$ & $\begin{array}{c}\text { Spesimen/ } \\
\text { Komposisi }\end{array}$ & $\mathrm{k}$ & $\begin{array}{c}\mathrm{L} \\
(\mathrm{m})\end{array}$ & $\begin{array}{c}V_{p} \\
\left(\mathrm{~mm}^{3}\right)\end{array}$ & $\begin{array}{c}\psi_{p} \\
\left(\mathrm{~mm} \mathrm{~m}^{3}\right) \\
/ \mathrm{s}\end{array}$ \\
\hline 1 & 10 & 30 & 120 & 35 & $\mathrm{~A}$ & $6 \times 10^{-4}$ & 6.594 & 2.572 & 0.10 \\
2 & 10 & 30 & 120 & 35 & $\mathrm{~B}$ & $6 \times 10^{-4}$ & 6.594 & 9.575 & 0.31 \\
3 & 10 & 30 & 120 & 35 & $\mathrm{C}$ & $6 \times 10^{-4}$ & 6.594 & 1.253 & 0.04 \\
4 & 10 & 30 & 120 & 35 & $\mathrm{D}$ & $6 \times 10^{-4}$ & 6.594 & 3.354 & 0.11 \\
5 & 10 & 30 & 120 & 35 & $\mathrm{E}$ & $6 \times 10^{-4}$ & 6.594 & 5.187 & 0.17 \\
\hline
\end{tabular}

Grafik laju keausan dengan variasi komposisi pada bahan polymeric foam dengan penguat fiberglass diperlihatkan pada gambar 8 dibawah ini.

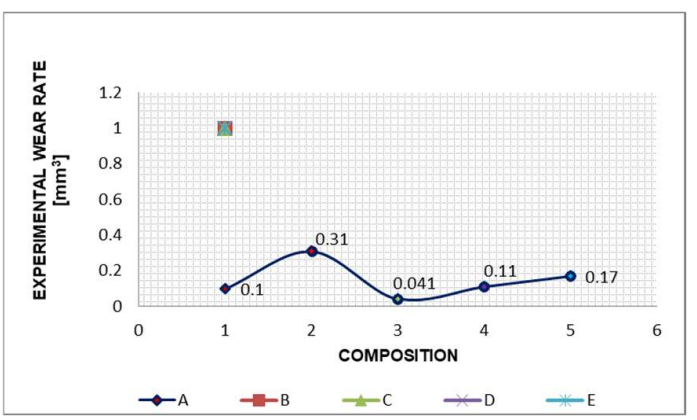

Gambar 8. Grafik Laju keausan Terhadap komposisi

Pada gambar 8 diatas laju keausan tertinggi terdapat pada spesimen B dengan nilai $0.31 \mu \mathrm{m}$ dan laju keausan terendah terdapat pada spesimen $\mathrm{C}$ dengan nilai $0.041 \mu \mathrm{m}$. Maka spesimen $\mathrm{C}$ bisa dikatakan memiliki tingkat keausan paling rendah dibanding komposisi $\mathrm{A}$, B, D dan E. Spesimen C ini dapat direkomendasikan sebagai komposisi membuat sepatu kuda yang dibutuhkan kaki kuda.

\section{KESIMPULAN}

Pengujian karakteristik keausan disimpulkan bahwa persentasi yang tinggi suatu bahan seperti resin dan polyurethane tidak menjamin bahan tersebut tahan terhadap keausan. Keseimbangan bahan dan teknik pengolahan bahan sangat berpengaruh. Hasil analisa menunjukkan komposisi B dengan kandungan resin $60 \%$, blowing agent 25\%, menghasilkan laju keausan terbesar sebesar $0.31 \mathrm{~mm}^{3} / \mathrm{s}$. Komposisi $\mathrm{C}$ menunjukkan nilai laju keausan terendah sebesar $0.041 \mathrm{~mm}^{3} / \mathrm{s}$ dengan komposisi resin 50\% dan blowing agent 30\%. Diharapkan Untuk peneliti berikutnya agar putaran dan beban dapat dijadikan variabel bebas karena adanya pengaruh signifikan putaran dan beban terhadap laju keausan.

Spesimen A nilai rata-rata untuk lebar jejak keausan (ā) $1616 \mu \mathrm{m}$, kedalaman jejak keausan $(\bar{b}) 546.17 \mu \mathrm{m}$, volume keausan eksperimental $\left(V_{p}\right) 9.575 \mathrm{~mm}^{3}$ dan laju keausan $\left(\psi_{P}\right) 0.10$ $\mathrm{mm}^{3} / \mathrm{s}$. Spesimen $\mathrm{B}$ dengan nilai rata-rata untuk lebar jejak keausan ( $\bar{a}) 2526.26 \mu \mathrm{m}$, kedalaman jejak keausan $(\bar{b}) 2033.18 \mu \mathrm{m}$, volume keausan eksperimental $\left(V_{p}\right) 2.573 \mathrm{~mm}^{3}$ dan laju keausan $\left(\psi_{P}\right) \quad 0.31 \mathrm{~mm}^{3} / \mathrm{s}$. Spesimen C nilai rata-rata untuk lebar jejak keausan $(\bar{a})$ $1079.87 \mu \mathrm{m}$, kedalaman jejak keausan (b) $266.10 \mu \mathrm{m}$, volume keausan eksperimental $\left(V_{p}\right) 1.253 \mathrm{~mm}^{3}$ dan laju keausan $\left(\psi_{P}\right) 0.041$ $\mathrm{mm}^{3} / \mathrm{s}$. Spesimen D nilai rata-rata untuk lebar jejak keausan (a) $1728.20 \mu \mathrm{m}$, kedalaman jejak keausan $(\bar{b}) 712.27 \mu \mathrm{m}$, volume keausan eksperimental $\left(V_{p}\right) 3.354 \mathrm{~mm}^{3}$ dan laju keausan $\left(\psi_{P}\right) 0.11 \mathrm{~mm}^{3} / \mathrm{s}$. Spesimen E nilai rata-rata untuk lebar jejak keausan $(\bar{a}) 1788.32$ $\mu \mathrm{m}$, kedalaman jejak keausan $(\bar{b}) 1101.40 \mu \mathrm{m}$, volume keausan eksperimental $\left(V_{p}\right) 5.187 \mathrm{~mm}^{3}$ dan laju keausan $\left(\psi_{P}\right) \quad 0.17 \mathrm{~mm}^{3} / \mathrm{s}$.

\section{UCAPAN TERIMAKASIH}

Pada kesempatan ini penulis ingin mengucapkan terima kasih kepada:

a. Prof. Dr. Ir. Bustami Syam MSMI selaku penanggung jawab Laboratorium Pusat Riset Impak dan Keretakan (IFRC) Departemen Teknik Mesin Universitas Sumatera Utara

b. Semua tim dan rekan yang ikut terlibat dalam penyelesaian penelitian ini yang tidak bisa disebutkan satu persatu.

c. Universitas Al Azhar khususnya Fakultas Teknik Prodi Teknik Mesin yang ikut mensukseskan dalam penerbitan jurnal penelitian ini.

\section{DAFTAR PUSTAKA}

[1]. Direktorat Jenderal Peternakan dan Kesehatan Hewan, 2017, Horse Population

Hal 6 dari 43 


\section{JURNAL ILMIAH TEKNIK MESIN, INDUSTRI,}

ELEKTRO DAN SIPIL

by Province, 2013 - 2017, sumber artikel: www.pertanian.go.id/NAK2017fix/Pop_Kuda_Prop_2017

[2]. Yuwono, A. H., 2008, Buku Panduan Praktikum Karakterisasi Material 1 Pengujian Merusak (Destructive Testing), Departemen Metalurgi dan Material Fakultas Teknik Universitas Indonesia, Jakarta.

[3]. ASTM G99-04 Standard Test Method for Wear Testing with a pin on disc Apparatus. Philadelpihia, PA : American Society for Testing and Materials.

[4]. Martín L,A, 2014, Alternative Materials For The Horseshoe, unpublished Bachelor Degree Project in Mechanical Engineering C-Level 22.5 ECTS Spring term, pp 4.

[5]. Mohammed M H, Dauda B 2014 Unsaturated Polyester Resin Reinforced With Chemically Modified Natural Fibre, IOSR Journal of Polymer and Textile Engineering (IOSR-JPTE) eISSN: 2348-019X, p-ISSN: 2348-0181, Volume 1, Issue 4 (Sep-Oct. 2014), PP 31-38

[6]. Rooney, J R D.V.M. "The Shape of the Equine Hoof" (1998)

[7]. Bahtiar, 25 Jun 2015, Manfaat menunggang kuda, sumber dari: http://nunggangjaran.blogspot.com/201 3/07/manfaat-berkuda.html. 